\title{
PERAN ETIKA PROFESI GURU MATEMATIKA DALAM MENGAHADAPI TANTANGAN ABAD 21
}

\author{
Wahyu $^{1}$, Wisnu Maulana², Muhammad Aidil Fitrisyah*3, \\ Zulkardi $^{4}$, Novita Sari ${ }^{5}$ \\ Universitas Sriwijaya ${ }^{1,2,3,4,5}$ \\ *e-mail: fitrisyahaidil055@gmail.com
}

\begin{abstract}
ABSTRAK
Penelitian ini bertujuan untuk mendeskripsikan peran guru matematika dalam menghadapi tantangan abad 21 yang semakin besar. Perkembangan dunia telah memasuki abad 21 yang dimana persaingan dalam dunia semakin ketat dan tidak terlepas dari perkembangan teknologi yang semakin pesat. Dalam menghadapi tantangan abda 21 guru matematika dituntut profesional di bidangnya, dimana pada abad 21 guru matematika dituntut dalam kompetensi karakter, keterampilan dan literasi dalam menciptakan sebuah pembelajaran. Hal tersebut merupakan sebagai tanggung jawab guru matematika dalam mempersiapkan siswa agar mimiliki kemampuan kolaborasi, berpikir kritis, kreatif, dan komunikatif. Selain itu peran guru pada abad 21 saat ni telah bergeser, peran guru menjadi fasilitator, motivator, nilai-nilai karakter, dan inspirator. Selain itu guru matematika diera abad 21 ini dituntut untuk menguasai iptek dan mampu memanfaatkannya dalam proses pembelajaran. Sehingga kemampuan guru terus berkembang sebagai bentuk kesiapan dalam menghadapi perubahan zaman yang silih berganti.
\end{abstract}

\section{Kata kunci :}

Etika profesi, kecakapan abad 21, pembelajaran matematika.

\section{ABSTRACT}

This study aims to describe the role of mathematics teachers in facing the growing challenges of the 21st century. The development of the world has entered the 21st century where competition in the world is getting tougher and cannot be separated from the increasingly rapid development of technology. In facing the challenges of you, 21 mathematics teachers are demanded to be professionals in their fields, wherein 21 mathematics teachers are required to be competent in character, skill, and century literacy in creating learning. This is the responsibility of the mathematics teacher in preparing students to have the ability to collaborate, think critically, creatively, and communicate. In addition, the role of teachers in the 21st century has now shifted, the role of teachers as facilitators, motivators, character values, and inspirers. In addition, mathematics teachers in this 21st-century era are required to master science and technology and be able to use them in the learning process. So that the ability of teachers continues to develop as a form of readiness to face the changing times

\section{Keywords :}

Professional ethics, 21st-century skills, mathematics learning

\section{PENDAHULUAN}

Dalam dunia pekerjaan, etika sangat penting dan harus dimiliki oleh seorang pekerja. Apapun itu pekerjaan setiap orang harus memiliki etika yang baik. Salah satunya guru, seorang guru harus memiliki etika yang baik karna mereka adalah suatu contoh yang akan ditiru oleh peserta didiknya. Maka dari itu dibuat lah suatu pedoman yang mengatur tingkah laku seorang guru yang dirumuskan pada suatu kongres PGRI yang pertama kali diadakan pada tahun 1973 dijakarta dan disempurnakan pada tahun 1989 dijakarta juga. Pedoman tersebut bernama kode etika guru indonesia yang berisikan 9 poin.

Dengan adanya kode etik guru ini, diharapkan bisa dijadikan tolak ukur seorang guru dalam bertindak, bersikap, dan berperilaku di kehidupannya, baik disekolah maupun dimasyarakat sekitar. 
Pada abad 21 ini. Banyak tantangan yang harus dihadapi oleh setiap kalangan dalam segala aspek kehidupan. Terutama dalam aspek pendidikan. Maka dari itu banyak upaya yang dilakukan untuk menghadapi tantangan tersebut. Salah satu upayanya adalah pengembangan guru matematika dalam mengajar.

Matematika sendiri merupakan ilmu yang sangat penting dalam semua ilmu di dunia ini. Bisa terlihat di indonesia sendirimatematika telah diajarkan dari jenjang pendidikan usia dini sampai jenjang perguruan tinggi. Dalam menghadapi tantangan abad 21. Seorang guru harus memiliki kompetensi profesional di pedagogik, kompetensi kepribadian dan kompetensi sosial. Selain itu juga guru terutama guru matematika harus memiliki keterampilan yang terdiri dari keteramlilan berpikir kritis, berpikir kreatif, komunikasi dan kolaborasi. Jika guru matematika tersebut telah menguasai semua keterampilan maka ia bisa menurunkan kepada peserta didiknya agar mereka juga memiliki keterampilan tersebt dalam pembelakaran matematika. Kompetensi dan keterampilan yang harus dimiliki seorang guru tersebut tak lepas dari etika yang harus di miliki guru tersebut. Jika guru tersebut memiliki etika yang baik. Entah itu didalam kelas maupun di kehidupan sehari-hari. Tidak menutup kemungkinan guru tersebut bisa memiliki kompetensi yang bisa menghadapi tantangan abad 21.

Oleh karena itu, penelitian ini bertujuan untuk mengkaji Peran Etika Profesi Guru Matematika Dalam Menghadapi Tantangan Abad 21.

\section{METODE PENELITIAN}

Penelitian ini menggunakan metode studi pustaka dengan pendekatan kualitatif, dengan mengkaji berbagai sumber ilmiah dan berbagai macam literatur yang terkait. Metode penelitian yang di gunakan meliputi sumber data, pengumpulan data, dan analisa data. Data yang telah diperoleh akan dikaji yaitu dalam bentuk hasil penelitian, buku, jurnal, dan proceedings yang terkait dengan topik yang dibahas.

Tahap analisa dimulai dengan pengumpulan sumber yang berhubungan dengan etika profesi guru matematika yang selanjutnya ditelaah kembali untuk mendapatkan informasi lebih lanjut. Hasill telaah yang telah didapatkan akan dikaitkan dengan kecakapan matematis abad 21.

\section{HASIL DAN PEMBAHASAN Etika Profesi}

Etika secara bahasa di bentuk oleh dua kata yaitu ethos dan ethikos. Ethos memiliki makna sebadgai sifat, watak, atau kebiasan. Sedangkan ethikos dapat diartikan sebagai susila, kelakuan, atau kelakuan baik (Fauzi, 2018). Menurut william (dalam wandi dan nurhafizah, 2019) mengartikan etika menjadi "A set of rules that define right and wrong conducts" maksudnya adalah rangkaian sistem yang menentukan mana tingkah laku yang benar dan mana yang salah.

Profesi menurut World Confederationof Organization for Teacing Profession (WCOTP) merupakan pekerjaan yang memerlukan sebuah persiapan yang relatif panjang dan dikhususkan kepada seseorang yang telah memiliki pendidikan tinggi dan pelaksanaannya diatur oleh kode etik. Sehinngga dapat disimpulkan bahwa etika profesi adalah sebuah standar yang diterapkan ke dalam sebah sistem dan organisasi yang digunakan di masyarakat sebagai aturan untuk melaksanakan tugas masing-masing individu.

Guru adalah adalah seseorang yang merncang, melaksanakan, dan menerapkan proses pembelajaran seta pembimbing yang melaksanakan kewajiban dalam pengabdian masyarakat (saondi dkk, 2010). Menurut UU No. 14 tahun 2005 tentang guru dan dosen, guru adalah pendidik profesional yang memiliki tugas dalam mendidik, mengajar, membimbing, mengarahkan, melatih, dan mengevaluasi siswa pada 
jenjang pendidikan baik formal ataupun nonformal.

Berdasarkan uraian diatas etika profesi adalah aturan, tata susila atau sikap yang harus dimiliki oleh guru dalam profesinya sebagai pendidik, pengajar, pelatih, pembimbing dalam mengabdi ke masyarakat. Etika profesi atau biasa disebut dengan etika kerja merupakan aturan yang dirancang atas kesepakatan pekerja dengan mengacu pada sumber dasar nilai dan moral. Rancangan etika kerja atau etika profesi yang telah disepakati dinamakan dengan kode etik. Kode etik sendiri meruakan referensi dalam mewujudkan berprilaku dalam melaksanakan tugas atau pekerjaan masing-masing. Dalam hal ini semua anggota wajib menghormati, dan mengikuti semua isi dari kode etik yang telah disepakati tersebut. Hal tersebut bertujuan untuk menciptakan suasana yang harmonis dan semua anggota merasakan adanya perlindungan saat melaksanakan tugas.

Di indonesia, profesi guru memiliki juga kode etik yang berisi tentang pedoman dalam berprilaku yang wajib di patuhi oleh semua guru yang secara profesional meaksanakan tanggungjawabnya sebagai guru. Kode etik guru di indonesia ditetapkan dalam kongres yang di hairi oleh PGRI dari seluruh indonesi. Adapun kode etik guru yang telah disempurnakan sebagai berikut:

1. Guru berbakti membimbing peserta didik dalam membentuk manusia seutuhnya dan berjiwa Pancasila

2. Guru memiliki dan melaksanakan kejujuran professional

3. Guru selalu berusaha memperoleh inforasi terkait peserta didik sebagai bahan melakukan pembinaan

4. Guru menciptakan suasana belajar baik yang mampu menunjang keberhasilan proses belajar mengajar

5. Guru memeliharan hubuungan baik dengan orang tua dan masyarakat dalam membina peserta didik dan rasa tanggung jawab terhadap pendidikan.
6. Guru secara pribadi dan bersama mengembangkan dan meningkatkan mutu dan martabat profesi

7. Guru memelihara hubungan kekeluargaan, seprofesi, dan kesetiakawan sosial.

8. Guru bersama-sama memelihara dan meningkatkan mutu organisasi PGRI

sebagai sarana perjuangan dan pengabdian

9. Guru melaksanakan segala kebijakan dalam bidag pendidikan.

Kode etik ini dibuat dengan harapan bisa dijadikan tolak ukur guru dalam mengambil tindakan, bersikap, dan berprilaku selama melaksanakan kewajibannya sebagai guru.

\section{Pembelajaran Matematika}

Matematika merupakan salah satu akar pondasi dari bidang ilmulainnya, sebab matematika dalam perkembanganya tidak pernah bergatung dengan ilmu lain melainkan menjadi pendukung dalam berbagai bidang ilmu lain dalam perkembangannya (kamarullah, 2017). Matematika juga berperan dalam membentuk cara berpikir dalam pemahaman dan penalaran dalam suatu permasalahan.

Menurut NCTM (Nation Coucil of Teachers of Mathematics) dalam pembelajaran matematika ada 4 prinsip dasar, antara lain: (1) Matematika sebagai pemecahan masalah, (2) matematika sebagai penalaran, (3) matematika sebagai komunikasi, dan (4) matematika sebagai hubungan. Sedangkan menurut UNESCO pembelajaran matematika memuat 4 pilar utama yaitu: kemampuan memahami (learning to know), kemampuan melaksanakan (learning to do), kemampuan mengomunikasikan (learning to live together), dan kemampuan meraih tujuan (learning to be).

Berdasarkan depdiknas (2006) tujuan dilaksanakannya pembelajaran matematika adalah agar siswa memiliki 


\section{$\pi$ (Phi)}

kemampuan dalam memahami konsep, mampu menggunakan penalaran, memecahkan masalah, mengkomunikasi ide dengan tabel, simbol atau gambar, dan mampu mengaplikasikanya dalam kehidupan sehari- hari. Dalam kurukulum 2013 pembelajaran matematika diberikan kepada siswa dengan tujuan memfasilitasi siswa agar memiliki kemampuan penalaran, komunikasi matematis, pemecahan masalah, koneksi matematis, dan representasi matematis. Sedangkan menurut kamarullah (2017) menyatakan bahwa tujuan dari pembelajaran matematika itu selalu menyesuaikan dengan kurikulum yang digunakan saat ini sehingga pembelajaran dapat terarah dan sesuai dengan tujuan yang telahditetapkan.

Berdasarkan hal tersebut pembelajaran matematika itu memberi pondasi kepada siswa dengan kemampuan berpikir kritis, sistematis, logis, kreatif dan bekerja sama. Sebab kemampuan tersebut diperlukan dalam bertahan hidup pada keadan zaman yang sering berubah-ubah sesuai dengan perkembangan IPTEK. Sehingga hal tersebut membuat proses pembelajran metamtika membutuhkan metode atau model pembelajaran yang mampu atau dapat digunakan guna mencapai tujuan pembelajran matematika yang telah ditetapkan.

Ada beberapa pendekatan atau model pembelajaran matematika yang diterapkan pada kurikulum 2013 yang dapat digunakan sebagi berikut:
1. Problembased Learning
2. Discovery Learning
3. Berbasis Proyek
4. Kontekstual
5. Inquiry

Dalam hal ini siswa di atur dalam sebuah kelompok yang saling berhubgan dalam sebuah aktivitas pembelajaran, sehingga dengan bekerja dalam suatu kelompok akan membantu meningkatkan
Jurnal Pendidikan Matematika Volume 5 Nomor 2 Tahun 2021

kemampuan atau potensi siswa dalam berpikir atau bertukar ide dan lain sebagainya.

\section{Kecakapan Matematika Abad 21}

Perkembangan zaman sudah memasuki abad ke-21. Tuntutannya juga semakin besar dan tidak hanya dengan pengetahuan konseptual untuk tetap bertahan, akan tetapi juga membutuhkan kecakapan yang lain, untuk bertahan di era modern saat ini dan sebagai upaya menghadapi tantangan abad 21. Dimana abad 21 merupakan tantangan pada bidang pendidikan dengan tujuan meningkatkan kompetensi sumber daya manusia. Terkait upaya dalam menghadapi tatangan abad 21, berbagai lembaga atau organisasi dan negara mulai fokus dalam mengembangkan berbagai kecakapan yang disebut dengan kecakapan abad 21 (Oktafianto, 2019).

Secara umum kecakapan abad 21 dibagi menjadi 4 kategori yaitu (1) cara berpikir, dalam hal ini yang dimaksudkan adalah kemampuan dalam berikir kritis, pemecahan masalah, dan pengambilan keputusan, (2) cara bekerja, dalam hal ini yang dimaksudkan adalah kemampuan berkomunikasi dan bekerja sama, (3) alat, (4) cara hidup, dalam hal ini diartikan sebagai sikap tanggung jawab dan kesadaran terhadap kompetensi dan budaya (binkley et al, 2018). Menurut Partnership for 21st Century Skills mengatakan ada enam elemen pokok pada kecakapan abad 21 yaitu menekankan pelajaran inti, menekankan keterampilan dalam pembelajaran, menggunakan media abad 21 dalam pengembangan keterampilan belajar mengajar dan belajar dalam konteks abad 21, mengajar dan mempelajari isi abad 21, dan menggunakan standar penilaian pada abad 21 dalam mengurkur kecakapan abad 21 (beers, 2011).

Sedangkan menurut Meteriti Grup dan North Central Regional Education Laborary keterampilan abad 21 dijabarkan 
menjadi 4 kategori sebagai berikut; literasi digital, pemikiran inventif, komunikasi efektif, dan produktivitas tinggi (Mayasari dkk, 2016). Berdasarkan definisi-definisi kecakapan abad 21 dapat dikatakan berhubungan dengan berbagai aspek kehidupan. Kecakapan abad 21 juga tidak memiliki posisi khusus dalam kurikulum pendidikan akan tetapi pendidikan pada abad 21 sekarang ini melibatkan aspek keterampilan dan pemahaman, dan menakankan oada aspek kreativitas, kolaborasi, dan kemampuan komunikasi selain itu keterampilan abad 21 juga berkaitan dengan teknologi dan moral yang menekankan pada kemampua berpikir kritis dan komunikasi (prayogi, 2020).

Keterampilan abad 21 diilustrasikan pada suatu skema yang dinamakan pelangi keterampilan abad 21 (Trilling, dan Fadel, 2009). Skema pelangi keterampilan abad 21 merupakan hasil adaptasi dari organisasi nirlaba p21 yang sedang mengembangkan kerangka kerja pendidikan abad 21 ke seluruh dunia.

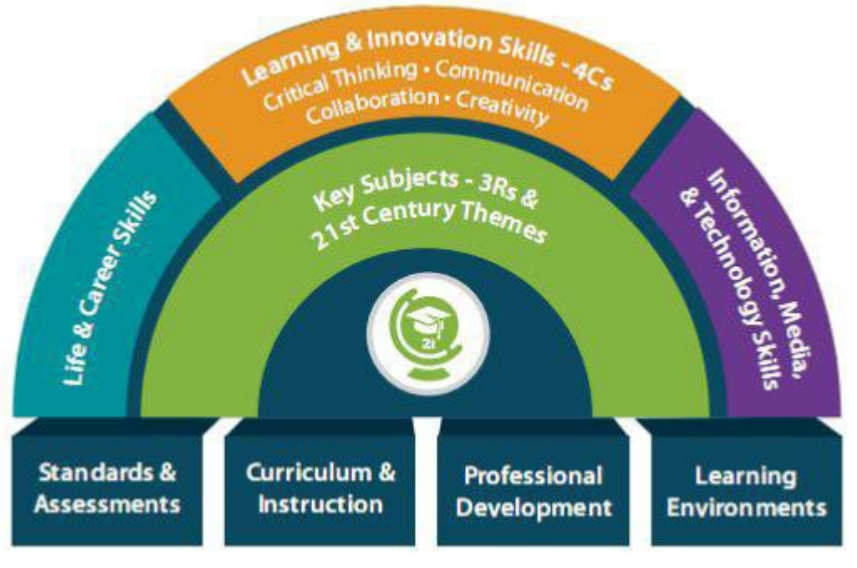

Gambar 1. Skema pelangi keterampilan abad 21

Berdasarkan pendapat terkait keterampilan abad 21, dapat disimpulkan bahwa pada era abad 21 ini setiap peserta didik harus menguasai 4 keterampilan atau yang dikena dengan 4C yaitu (1) keterampilan berpikir kritis (critical thinking) merupakan kemampuan berpikir tingkat tinggi yang bukan hanya terkait dengan hafalan akan tetapi juga mampu mengunakan dan memanipulasi materi sesuai dengan kondisi yang dihadapi, (2) keterampilan berpikir kreatif (creative thinking) merupakan kemampuan dalam menciptakan hal baru baik itu ide atau karya, (3) keterampilan komunikasi (communication) merupakan kemampuan individu dalam menyampaikan ide atau pendapat kepada orang lain sehingga terjadinya interaksi sosial, dan (4) keterampilan kolaborasi (collaboration) merupakan kampuan dalam bekerja sama untuk mencapai tujuanyang telah ditetapkan.

\section{Peran Etika Profesi Guru Matematika Dalam Menghadapi Tantangan Abad 21}

Perkembangan ilmu pengetahuan dan teknologi (IPTEK) semakin berkembang dan tidak bisa dihindari lagi. Sehingga berdampak hampir semua bidang, termasuk dunia pendidikan. Perkembangan IPTEK sendiri tidak lepas dari pengaruh matematika karena dalam perkembangan matematika dengan teknologi saling berhubungan satu sama lain. Leh karena itu perkembangan yang pesat dibidang tersebut dilandasi oleh perkembangnya matematika dibeberapa cabang matematika. sehingga menguasai 


\section{$\pi$ (Phi)}

teknologi diperlukan pengusaan matematika yang baik. Terlebih lagi dunia sekarang sudah memasuki perkembangan abad 21 dimana tantangan yang akan dihadapi akan lebih besar di bandingkan dengan era sebelumnya.

Guru matematika pada masa abad 21

harus menghadapi tantangan dalam melakukan akselerasi terhadap perkembangan IPTEK. Selain harus memperhatikan berbagai kebijakan yang dikeluarkan oleh kemendikbud, dan kode etik guru atau etika profesi dalam mengajar, tetapi guru juga ditantang untuk mampu mengatasi tantangan yang datang dari perkembangan zaman. Dimana pembelajaran harus disesuaikan dengan kebijakan, etika profesi, dan tantangan di masa abad 21.

Adapun tantangan yang harus dihadapi oleh guru pada pembelajaran abad 21 adalah guru harus mampu menekankan pembelajaran kepadaa kemampuan berpikir kritis siwa, guru harus mampu menghubungkan ilmu atau materi yang dipelajari dengan dunia nyata, menguasai teknologi dan komunikasi, dan berkolaborasi (Trisdiono dan muda, 2013). Sehingga pada era abad 21 ini guru matematika tidak hanya dituntut menguasai materi pembelajaran, akan tetapi dituntut juga dalam pengusaan teknologi dan mampu menciptakan kondisi belajar yang menunjang tercapainya tujuan dari pembelajaran matematika dengan memperhatikan kode etik guru.

Menurut Marto (2020) mengatakan perngembangan guru matematika sebagai tenaga profesi harus memenuhi beberapa persyaratan kompetensi dalam melaksanakan tugas dan wewenangnya secara profesional, kompetensi profesional dimaksud bukan hanya di nilai dari setifikasi. Akan tetapi dilihat dari kemampuan guru dalam menghadapi tantangan abad 21. Dimana guru dituntut memiliki kompetensi profesional di pedagogik, kompetensi kepribadian dan kompetensi sosial.

Adapun kempetensi profesional guru matematika sebagai berikut: (1) mengusai bidang studi matematika dan metodelogi matematika, (2) menguasai secara fasih materi kurikulum dalam bidang matematika, (3) menguasai dan memanfaatkan teknologi inpormasi dalam kegiatan pembelajaran, (4) mampu mengorganisasikan materi kurikulum, dan (5) meningkatkan kuaitas pembelajaran melalui penelitian tindakan kelas. Sementara pedagogik yang harus dikuasai oleh guru matemaika adalah mampu memahami karakteristik siswa sehingga guru bisa mengambil atau melakukan tindakan yang sesuai dengan kondisi siswa sehingga dapat meningkatkan kemampuan siswa secara optimal agar tercapainya tujuan pembelajaran matematika.

Selain itu guru matematika dalam menghadapi tantangan abad 21 harus mengembangkan beberapakompetensi sosial, antara lain: mampu berkomunikasi secara efektif dan empatik, berkontribusi terhadap dunia pendidikan baik sekolah atau masyarakat, mampu memanfaatkan IPTEK dalam proses pembelajaran dan mengembangkan diri, dan menunjung tinggi kode etik guru.

Berdasarkan uraian diatas, guru matematika yang profesional dalam menghadapi tantangan abad 21 memiliki ciri - ciri profesional yang dikaitkan dengan mengacu pada kode etik guru seperti:

1. Memiliki wawasan luas

2. Memiliki rasa tanggung jawab baik kepada sekolah ataupun masyarakat

3. Mampu mengatasi kesulitan belajar siswa

4. Memfasilitasi pengembangan potensi siswa

5. Mampu menguasi materi dan rinsip dalam pembelajaran 
6. Mampu

merancang

konsep pembelajaran yang melibatkan siswa

7. Menguasai teknologi

Dan kompetensi terakhir yang harus dimiliki guru dalam menghadapi tantangan abad 21 ada 5 komtepetensi sebagai berikut:

1. Karakter. Dalam hal ini karekter yang dimaksud adalah bersifat akhlak (jujur, amanah, sopan santun, dan dapat dipercaya) dan karakter dalam bekerja (kerja keras, bertanggung jawab, disiplin, dan gigih).

2. Kritis, kreatif, kolaboratif dan komunikatif. Keterampilan ini lebih dikenal dengan keterampilan 4C yang dimana keterampilan ini penting dimilki seorang guru guna mendorong atau memotivasi siswa agar siap menghadapi perubahan zaman.

3. Literasi. Literasi merupakan dasar untuk guru agar dapat menghadirkan pembelajaran yang lebih variatif dan tidak monoton sehingga guru mampu menerapkan berbagai model pembelajaran.

4. Menyediakan bahan pembelajaran sesuai dengan kemampuan siswa.

5. Mampu melakukan autentic learning.

Konsep pembelajaran diatas sesuai dengan arahan mentri pendidikan pada hari guru nasional 25 november 2019, dalam upaya menghadapi tantangan zaman. Dimana diperlukan guru penggerak yang harus merdeka dalam membuat inovasi atau gagasan dalam proses pembellajaran dengan siswa sebagai fokus utama dalam merdeka belajar. Sehingga guru matematika di era abad 21 sekarang harus terus berkembang untuk kedepannya.

\section{SIMPULAN}

Berdasarkan penelitian yang telah dilakukan, dapat diambil kesimpulan bahwa penelitian ini menunjukan bahwa etika profesi guru itu sangat berperan dalam pembelajaran,dan dilingkup pekerjaan, karena dalam suatu pembelajaran khususnya matematika hal tersebut menjadi salah satu pondasi bagi guru untuk mencapai suatu tujuan, dan sebagai arah atau pedoman guru dalam berprilaku atau bertindak selama proses pembelajaran berlangsung. Selain itu etika profesi guru juga memiliki pengaruh terhadap kecakapan abad 21, dimana guru harus bisa melibatkan keterampilan, pemahaman dan menekankan pada aspek kreativitas, kolaborasi, berpikir kritis dan kemampuan komunikasinya yang harus dikuasai oleh siswa sebagai persiapan menghadapi tantangan dimasa yang akan datang, terkhusus pada pembelajaran matematika. Adapun tantangan yang dihadapi profesi guru matematika dalam pembelajaran abad 21 saat ini yaitu: Guru harus kreatif dan inovatif mengembangkan mediaatau model dan lain sebagainya sesuai pembelajaran abad 21, Guru juga harus meningkatkan kompetensinya, baik pada kompetensi bidang pembelajaran, ataupun dalam pelaksanaan tugas dan fungsinya. Selain itu peran profesi guru juga harus memiliki kemampuan berkomunikasi dengan baik pada abad 21.

Saran untuk penelti selanjutnya yaitu: dapat meninjau kembali solusi untuk menghadapi tantangan kecakapan abad 21 yang dihadapi oleh guru matematika dan langkah-langkah yang harus di lakukan untuk kedepannya.

\section{DAFTAR PUSTAKA}

Afifah, M. N. (2019). Keterampilan Abad 21 Dalam Pembelajaran Matematika Berbasis Proyek (Doctoral Dissertation, UIN Sunan Ampel Surabaya).

Beers, S. (2011). 21st Century Skills: Preparing Students For Their Future.

Effendi, L. A. (2012). Pembelajaran matematika dengan metode penemuan terbimbing untuk meningkatkan kemampuan 
representasi dan pemecahan masalah matematis siswa SMP. Jurnal Penelitian Pendidikan, 13(2), 1-10.

Fauzi, I. (2018). Makna Etika. In I. Fauzi, Etika Profesi Keguruan (p. 9). Jember: IAIN Jember Press.

Gazali, R. Y. (2016). Pembelajaran matematika yang bermakna. Math Didactic: Jurnal Pendidikan Matematika, 2(3), 181190.

Kamarullah,

K.

(2017).

Pendidikan matematika di

sekolah kita. Al Khawarizmi: Jurnal Pendidikan dan Pembelajaran Matematika, 1(1), 2132.

Kesumawati, N. (2008). Pemahaman konsep matematik dalam pembelajaran matematika. Semnas Matematika dan Pendidikan Matematika, 2, 231-234.

Mahanal, S. (2014). Peran Guru Dalam Melahirkan Generasi Emas Dengan Keterampilan Abad 21. In Seminar Nasional Pendidikan HMPS Pendidikan Biologi FKIP Universitas Halu Oleo (Vol. 20, Pp. 1-16).

Mariyana, R. (2010). Etika Profesi Guru. Etika Profesi Guru.

Mayasari, T., Kadarohman, A., Rusdiana, D., \& Kaniawati, I. (2016). Apakah Model Pembelajaran Problem Based Learning Dan Project Based Learning Mampu Melatihkan Keterampilan Abad 21?. Jurnal Pendidikan Fisika Dan Keilmuan (JPFK), 2(1), 48-55.

Nahdi, D. S. (2019). Keterampilan Matematika Di Abad 21. Jurnal Cakrawala Pendas, 5(2).

Oktafianto, W. R. (2019). Analisis Aspek Kecakapan Abad 21 Pada Buku Teks Fisika Kelas X (Doctoral Dissertation, Universitas Negeri Semarang).
Prayogi, R. D. (2020). Kecakapan Abad 21: Kompetensi Digital Pendidik Masa Depan. Manajemen Pendidikan, 14(2). Qomari Anwar dan Syaiful Sagala.Profesi jabatan Kependidikan dan Guru Sebagai Upaya Menjamin Kualitas Pembelajaran, (Jakarta: Uhamka Press, 2004), hlm. 131

Richardo, R. (2017). Peran ethnomatematika dalam penerapan pembelajaran matematika pada kurikulum 2013. LITERASI (Jurnal Ilmu Pendidikan), 7(2), 118-125.

Septikasari, R., \& Frasandy, R. N. (2018). Keterampilan 4C Abad 21 Dalam Pembelajaran Pendidikan Dasar. Tarbiyah Al-Awlad, 8(2), 107-117.

Sidiq, U. (2018). Kode Etik Guru. In A. Ikhwan (Ed.), ETIKA DAN PROFESI KEGURUAN (p. 51). Tulungagung: STAI Muhammadiyah Tulungagung.

Trilling, B., \& Fadel, C. (2009). 21st Century Skills, Enhanced Edition: Learning For Life In Our Times. John Wiley \& Sons.

Undang-Undang Guru dan Dosen No. 14 Tahun 2005, $2009: 2$

Wandi, Z. N., \& Nurhafizah, N. (2019). Etika Profesi Guru Pendidikan Anak Usia Dini. Golden Age: Jurnal Pendidikan Anak Usia Dini, 3(1).

William C. Frederick; Keith Davis; James E. Post,. 1988. Business and Society, Corporate Strategy, Public Policy, Ethics, Mc Graw-Hill, Publishing Company.

Zulhimma, Z. (2013). Eksistensi etika profesi keguruan dalam dunia pendidikan. LOGARITMA : Jurnal Ilmu-ilmu Kependidikan dan Sains, 1(2), 97-110.

Trisdiono, H., \& Muda, W. (2013). Strategi pembelajaran abad 21. Yogyakarta. Lembaga Penjaminan Mutu 
Pendidikan Prov. DI Yogyakarta.

Tersedia online.

Marto, H. (2020). Perkembangan

Guru Matematika Era 4.0.

Aksioma, 9(1), 13-21. 